\title{
The Role of Culture in Managing Biodiversity: The Case of the Karanga Community in Zvishavane, Zimbabwe
}

\author{
Chamunogwa Nyoni \\ Department of Social Work \\ Bindura University of Science Education \\ nyonic2008@gmail.com \\ Obediah Dodo \\ Department of Peace and Governance \\ Bindura University of Science Education \\ obeddodo@gmail.com
}

\section{ABSTRACT}

The concept of biodiversity is not new among traditional communities in Zimbabwe. Traditional communities have always ensured biodiversity from time immemorial. They have always co-existed with their environment and have always appreciated the importance of biodiversity in life. As a result, they have employed various measures to ensure this. Much of the measures that have been done are premised on the observations from culture. This paper sought to establish various cultural measures that have been relied upon by the traditional communities in Zimbabwe to promote the concept of biodiversity. The paper tackles the threat to cultural mechanisms in the management of biodiversity. The paper argues that 'totemism', taboos and superstitions have been relied upon as measures employed to safeguard biodiversity among the traditional Karanga ethnic group of Zvishavane. The paper further observes that culture has been a vehicle for promoting co-existence among the different species of the world.

\section{Keywords:}

totemism, culture, biodiversity, indigenous knowledge systems

\section{Introduction}

7 raditionally, biodiversity is a concept that is used to nurture peace and continuity 1 through its mere existence. It is a value that has been imbedded in the social systems of most African cultures, the Karanga people included. Social ideals, norms and customs shape people's relationships with the surrounding existing world, and ethics also play a role in bettering people's understanding. The concept behind traditional conservation of biodiversity focuses on several areas: 'totemism', taboos, superstition and myth amongst others. All these put together are what this discussion will term 'targeted avoidance' though some scholars tend to either confuse them or interchange their meanings. 
Since time immemorial, biodiversity has been employed to preserve the natural environment and the system has worked well over the period till probably the advent of globalisation and modernity when the law trivialized home-grown knowledge and officially disempowered traditional leadership structures that policed and upheld the sanctity of traditions. It is, therefore, the intention of this paper to look at various cultural measures that have been relied upon by the traditional community in Zvishavane, Zimbabwe to promote the concept of biodiversity. Sustenance and the passing down of some of these values and concepts which are collectively termed indigenous knowledge require a systematic mode of management. Indigenous knowledge, as reflected by Attech (1991) is knowledge that is embodied in culture and is an integrated pattern of human knowledge, beliefs and behaviour, customs, taboos, rituals, ceremonies, institutions and folklore. According to Melchias (2001) indigenous knowledge system is what indigenous people are knowledgeable about and perfectly do, and what they have sustainably practised for generations. Indigenous knowledge is thus knowledge that is derived from a people's culture and way of life. This is the information that has been employed by indigenous societies to develop and maintain their lives for so long as they live. This essential band of knowledge is, however, threatened by modern science and globalisation.

\section{Background}

The Karanga ethnic group of Zvishavane is one of the many Karanga ethnic groups scattered in Zimbabwe. The Karanga people of Zvishavane have over the years relied on their resources for daily sustenance and development. These resources have been conserved through some socially accepted means; that satisfied everyone as they strongly believed in communalism. The responsibility to police the equitable use of resources was placed on both the people and their local leadership. However, there was also some important spiritual component of the ancestors which played an overall role of administration and management.

The Karanga people of Zvishavane have a deep sense of communalism and a well knit relationship in almost the entire community through the recognition of totems and observation of myths and other inter-marriage systems. That way social, political, economic and all other fronts are maintained cordially. The district is mostly inhabited by people of the Hungwe totem. All these have a common ancestor who can be traced back to the Mutapa Empire. Of late, it has however been realised that some of the traditionally valued natural resources have been waning away through abuse and improper management. The area of Zvishavane is generally endowed with a variety of flora and fauna: musasa, munhondo, loquat tree, fig tree, baobab, Lophira alata and various medicinal shrubs which traditionally provided both medicinal and food requirements. Most of these resources and knowledge systems are very threatened. Besides flora and fauna, there is also a variety of animal species: hare, duikers, pangolins, antelopes, crocodiles, birds and fish that also provided with both meat and medicinal requirements. 
Zvishavane District is located in the province of Midlands. It is home to many minerals like gold, platinum, chrome, asbestos and nickel. The area receives very sparse rainfall of less than $650 \mathrm{~mm}$ per year making the area susceptible to recurrent droughts.

\section{Methodology}

An intensive mixed methodology comprising desk study of essential literature that include policy documents, official communiqué, past research journals and other traditional position papers, transect walks in the study area and in depth interviews with key informants were employed to produce this paper. Data gathering stretched over a long period of over a year and half in which in-depth interviews with focal people were done. To analyse the data, the study made use of the content analysis and thematic methods which clearly identified prominent themes from all the respondents and the documents and perused literature.

Some of the earliest studies around the preservation of people's heritage through the use of traditional morays and taboos were researched by Emile Durkheim, and Talcott Parsons, (Marshall 1994). These scholars believed that naturally society needed some superhuman force to regulate behaviours: and these could only be found in the association of some behaviour to some special natural resources and or attaching misfortunes to some socially unacceptable conduct. It is against this conception by Durkheim and Parson that this study was conducted.

\section{Target Population and sample}

This study was limited to the Karanga people of Zvishavane. The study employed purposive sampling to come up with a sample size of the respondents. All the three chiefs of the Karanga people in Zvishavane notably chief Masunda, Chief Mazvihwa and Chief Mapanzure were reached in this study while twenty-five village heads were also relied upon to provide information on the role of culture in managing biodiversity among the Karanga people. Key informant interviews were also extended to two 'masvikiro' who served as rain makers and three chiefs' aides renowned for their knowledge of the indigenous people.

\section{Justification of the Study}

The Karanga people are one of the ethnic groups in Zimbabwe. Zimbabwe is made up of different ethnic groups that can, however, be broadly categorised into two classes: the Shona and the Ndebele people. The Shona are generally found in the east, central northern and north-western and south-eastern parts of the country and generally constitute about 84\% (Sithole and Makumbe, 1997). The Ndebele people are in the southern and western parts of the country constituting about $12 \%$ of the entire population (Sithole and Makumbe, 1997, Ndlovu-Gatsheni, 2008). However, on a closer look, the demographic distribution of the same ethnic groups is as follows; Zezuru about $18 \%$, the Karanga about 22\%, the Ndebele about 19\%, the Korekore about $12 \%$ and the Manyika about $13 \%$ and the Ndau 3\% (Ibid). 
The Karanga people are located in the Masvingo province and some parts of the Midlands province. Despite the Karanga people's demographic dominance, this has not translated in their visibility and dominance in most spheres of governance. There is very little that is written and known about the Karanga people's culture in the new era and millennium. This is despite the fact that this is a group of people which has a rich pre-colonial history dating back to the pre Mwene Mutapa era. The Karanga people have lived on the shadows of other dominant groups especially the Zezuru and Manyika resulting in the absence of documentary information and evidence of their lives. The Karanga people of Zvishavane have from time immemorial been in close contact with the Ndebele making them potential candidates to borrow from the Ndebele culture and also affect the Ndebele culture in turn. What has happened from the Karanga people's contact with the Ndebele has not been captured. This particular research seeks to fill the void of providing documented evidence of the Karanga cultural group that has been in constant contact with the Ndebele. Furthermore there has been an outcry from the Zimbabwean chiefs that as custodians of the culture they are overlooked in many development initiatives as people look up to globalisation for development answers yet they remain key and indispensable to development.

\section{Theoretical Framework}

This study is underpinned on the Matrix-Based Conservation Theory. The basic premise of matrix-based conservation theory is that it is essential to maintain suitable habitat and populations of native species outside of large reserves, i.e., in the matrix (Lindenmayer and Franklin 2003).

\section{Results and Discussion}

\section{Biodiversity}

The concept of biodiversity is held in high acclaim by the Karanga people. Focus group discussions and in depth interviews note and recognise the dynamism in traditional governance of natural resources which has seen the interchangeability of terms; environmental conservation, resource preservation, environmental governance and biodiversity: all driving towards the delivery of a common agenda. In the Karanga traditional mode, the concept is carried behind and supported by the association and relationship to prominent living creatures in respective areas as a way of ensuring the preservation of the latter. The respondents pointed out that the chiefs were the custodians of the environment and as such they were mandated to ensure the co-existence of all species. The above facts have also been highlighted by such some scholars as Ranger (2003) and Fabricius (2004) who argue that religious leaders: chiefs and spirit mediums carried out an invaluable responsibility in natural resource conservation. Others like Nhira and Fortmann (1993) in Mukwada (2008) identified the groups of controls through which they argued traditional local institutions managed resources, including sacred controls and pragmatic controls. It is the sacred control alternately presented as norms of control based on myths or natural religion 
and enforced by community endorsement or traditional leaders that Gelfand way back in 1979 termed 'rules of avoidance' while several other scholars (Haralambos and Holborn, 2000, Pfukwa, 2001, Chigidi, 2009, and Masaka and Chemhuru, 2011) called it taboos 'contra bonos mores'. Jones (2002) concludes that the use of natural resources was locally controlled by cultural norms and rules which were enforced through traditional leaders such as the chiefs.

There is also another school of thought that includes the likes of MohamedKaterere and Chenje (2002) which argues that community-based natural resource conservation structures that existed in Zimbabwe were brought down by colonialists through the establishment of western-desired land husbandry models: Native Act of 1923, Land Apportionment Act of 1931, Forest Act in 1949 and Land Husbandry Act of 1951 amongst others. These models were intended to displace traditional systems that were considered barbaric by the colonialists Europeans. Interviews with key respondents indicated that Africans have always been conservationists to the core.

\section{Taboos}

The belief in taboos is an old approach to the management and regulation of people's behaviour in particular societies. It is a concept which Dodo (undated) has argued as not enshrined in any written law but was simply kept in the traditions and used to instil fear in people as a way of restraining them from an unacceptable activity. Relatedly, Amobola (2013) also concur that taboos were established to control the moral order of the society and are intensely entrenched in the culture as well as the religious beliefs of a society. Taboos apply as a set of social norms and assist to clarify the division between what is suitable and not. Whereas diverse cultures have a variety of taboos, the general rationale for all of them is the same: regulation through an element of danger that befalls those who break it (Ibid).

Despite the fact that taboos are not written anywhere, they are nevertheless passed down to younger generations through some social mechanisms which then socialise them into its religious beliefs, norms, values and collective opinions of the entire society through its traditional ways of knowledge seeding. Whereas there are taboos that are only common in particular cultures, there are some taboos that are believed to be worldwide; incest which prohibits same family sex, cannibalism which is against the consumption of human flesh, swearing, which is about the use of vulgar language, and murder amongst others.

In the Shona people and particularly the Karanga of Zvishavane, taboos present a set of regulations helping as an ethical control in the society to guarantee peace and security and cordial relations across the community. As aptly put by Gelfand, Pfukwa (2001), Tatira (2000b) and Madu (2002), taboos can be classified according to either the things that they seek to protect or the effect that they produce upon infringement like: food, health, environment, death, safety, 'unhu'-enforcing and wealth. Therefore, in the Karanga community, it is believed that 'ukarova amai unotanda botso' that if one assaults a mother, misfortunes befall. This is a social regulation that was instituted simply to protect vulnerable mothers from the wrath of their rowdy children. Over time, this taboo has been accepted to an extent that it is almost real. In 
Zvishavane, there are selected groves where people usually harvest loquats 'mazhanje' and stinkbugs 'encosternum delegorguei Spinola' and are required to harvest only enough for their needs and never take any excess. It is believed that if one exceeds requirement or say out vulgar language, he/she loses directions for the exit route till the family performs some appeasement rituals. In the same groves, culturally, people are not allowed to enter for the purposes of praying. What the regulation tried to achieve was equitable use of resources and proper conservation so that there could be some continuity in years to come. These groves had proved to be secure sources of food especially in times of famine.

Within the Zvishavane Karanga society, some people accept as true that trees and forests are the expression of the authority of the Supreme Being. These people believe that such forests and trees are the ideal sites to meet with their Supreme Being and several other consultations and rituals like 'mukwerera', rain-making ceremonies. Some of the trees, tree-barks, leaves, roots and grasses are considered medicine to both humanity and animals. It is also believed that any abuse of such sites could invite misfortunes from the spirits of the area. Effectively, this belief helped conserve some of the endangered trees and much needed forests for other developments and projects.

Traditionally, among the Karanga of Zvishavane fishing or killing frogs and crabs in drinking water sources were stringently forbidden. It was believed that it was some of these creatures that safeguarded water and helped to produce more of it. Therefore, killing these creatures meant that the sources were going to dry up. However, what the elders simply feared was the destruction of pond edges by fishing people and that if people killed frogs that was bound to contaminate water. Some tree species have largely been protected owing to the observance of taboos.

\section{Tree Species}

All fruit trees among the Karanga people are not supposed to be cut for use in such communal use as firewood or and pole use. According to the respondents, fruit trees are critical in the maintenance of food especially balanced and diverse food. The area is rich with different fruit trees among them chakata (wild plums), nhengeni (ximenia caffra), chechete, hubvu (vitex payos), suma, hlagahuwe also known as sosoti and mapfura (marula). In addition to the above such rainmaking trees such as muchakata and mubvamaropa are prohibited from being cut. The respondents also noted that the cutting down of very 'big and old' trees requires authorisation from the chief or his immediate emissary. According to the respondents trees also known for their medicinal, nutritional, domestic and cultural value are forbidden to be cut. These include mubvamaropa, musasa, muchakata and murumanyama believed to cure stomach ailments.

\section{Totemism}

According to African beliefs, totems give way for ethical codes to promote peace and order in particular societies. Totems are a component of everyday life and are passed down from one age group to another watched over by society, primarily to direct the 
behaviour of members (Kilonzo et al, 2009). They serve a unifying function amongst descendants of the same clan and regulate their relations with natural resources. Like taboos, totems also serve to preserve fauna and flora in the forest and have therefore helped guarantee ecological biodiversity. Karanga people in Zvishavane all carry an animal or bird totem which inherently disqualifies the person from feasting on that respective animal or bird. This is a measure of protecting biodiversity. What totems simply do in society according to the key respondents is restrain members of a particular clan from "kudya mutupo" (eating their "totem) with the those that go against the advice told of the dire consequences such as falling of the teeth. Those of the Hungwe totem (Bird) are forbidden from eating the bird and the Mpofu people are supposed not to eat the eland. Clans whose totems for examples are of predatory animals consider all predatory animals sacred. Respondents also noted that on the strength of the individual's totem, one should never harm his or her 'totem animal'.

Totems also prohibit the same clan from either marrying or engaging in sex as a way of maintaining relations and sustaining the clan. In other words, totemism tells us that once-upon-a-time, people sharing the same totem would have originated from the same family branch if not the same great grandfather. Even if people were to meet in a foreign land, engaged for possible marriage, the moment they discover sharing a similar totem, that love relationship is supposed to cease. Marrying a relative is said to 'defile the land' with dire consequences on the lives of various living organisms chief among the effects is drought. In this respect, people still maintain biodiversity in their areas. However, if they proceed because of some other reason, the husband is expected to pay a beast as a gesture of severing a 'previously existing' relationship 'mombe yecheka ukama' so that a new marriage may be recognised.

Regarding the relationship between people and animals, totemism also plays an important role towards the protection of some animals from mankind especially the most endangered species. The concept simply direct that people of a particular totem cannot take it as meat neither can they play around or abuse it for anything else. This position was designed primarily to ensure that particular groups of people have some responsibility to conserve a particular type of animal. In most cases, animals chosen for taboos were the most endangered ones in that area; therefore implying that they were now saved from potential hunters.

\begin{tabular}{|c|c|c|c|}
\hline Totem & $\begin{array}{c}\text { Animal/ } \\
\text { Plant }\end{array}$ & Area & Implication \\
\hline Soko & $\begin{array}{l}\text { Monkey } \\
(\text { tsoko })\end{array}$ & $\begin{array}{l}\text { Masunda } \\
\text { chieftainship }\end{array}$ & $\begin{array}{l}\text { If one eats a monkey, he/she loses teeth. This } \\
\text { has helped preserve monkeys in the area. } \\
\text { Because tsoko (monkey) and gudo (baboon) are } \\
\text { assumed to be 'brothers' those of the Soko } \\
\text { totem do not feed upon the baboon as well. }\end{array}$ \\
\hline Hungwe & Bird & $\begin{array}{l}\text { Masunda } \\
\text { chieftainship }\end{array}$ & Teeth fall and this protects the fish eagle. \\
\hline Hove & Fish & $\begin{array}{l}\text { Mazvihwa } \\
\text { chieftainship }\end{array}$ & $\begin{array}{l}\text { Teeth fall and this has been used to protect the } \\
\text { fish species }\end{array}$ \\
\hline
\end{tabular}




\section{Sacred Reptile Species}

There are sacred reptile species that must not be killed in this Southern area of Midlands. The sacred reptile species include some snakes such as shanga nyoka and shato as well as frogs. They are revered and must not be killed under any circumstances according to the respondents. Frogs are supposed not to be killed with respondents noting that if one does that water sources are bound to dry. The above belief is reinforced in the cultural thinking that "hapana mvura isina chura/zura/datya" implying that there is no water without a frog.

\section{Shanga nyoka (house snake)}

This snake type is said to be tied to ancestral worship and is considered very friendly. People in this area are thus prohibited from killing this snake species. Anyone known to have killed this snake is summoned to the chief's kraal and heavily censored for such an abomination according to key informant respondents.

\section{Python}

The python like the shanga nyoka is said to be a very human friendly snake and is tied to ancestral worship as well with the snake also noted to have great attachment in rain making ceremonies. Anyone who goes against the decree to protect this 'friendly' snake faces great censorship from the chief and is fined very heavily. Respondents noted that undue killing of the snake could result in unforeseen calamities falling the area that include droughts and animal pest and diseases break out. That way the python species is protected.

\section{Wild Life Protection}

The Karanga people of Zvishavane enforce wildlife conservation through a number of measures that include the banning of wildlife traps (zvidzingi) and avoidance of indiscriminate hunting of animals. Key informants reflected that it is believed that wanton killing of animals and birds invoked the anger of the spirits resulting in the communities falling to omen. In this way Booth et al (2004) observe that this act enables societies to conserve their natural resources without any written legislation. Respondents noted that the leopard is another endangered species that is not supposed to be killed in this area. They noted that one needs authorisation from the chief to kill a leopard in this area. Furthermore, the respondents said that in the community certain sacred places were closed to hunting especially the areas believed to be home to the remains of the chiefs. Plants and grass around the grave sites are perceived to be sacred and should not be burnt or cut. The researcher observed a case that was brought before the chief's dare of a man who had cut down "mumvuri wamai vedu pavakarara" (a shade where our mother is interred). The man was subsequently fined three cows for the offence for breaching traditional rule. 


\section{Superstition}

This is a belief that is derived on falsehoods or actions that cannot be proven (Kagan, 2012). Superstitions basically signify the fundamental innate fright of mankind, caused by the uncertainties of this world (Kumar 2009). It is an illogical conviction that an act not reasonably connected to a course of proceedings influences its conclusion. Therefore, superstitions are diverse in nature and definition as they are found in religious, personal and cultural domains.

Superstitions have traditionally been used to some extent, to protect the wellbeing of some endangered elements in societies. These have also been applied to children as a way of deterring them from engaging in criminal and other immoral activities. In the Shona culture in general, there is a belief that if you are travelling and a squirrel attempts to cross your path/road, it is a sign that your journey is likely to face serious misfortunes. What is generally known is that squirrels are naturally fast animals that find it easy to cross roads before human traffic pass them. Therefore, it is rare for one to turn back or make an attempt before it is convinced that it will successfully cross.

\section{Relevance of Biodiversity in the Contemporary World}

Biodiversity has been a relevant facet of the traditional society as it has managed to help conserve traditional heritage in its all forms. A long time ago, local people did not rely on the western forms of social services like health and education. Rather, they made use of their traditionally developed mechanisms which worked wonders (Meakin, 1993). These forms of knowledge were transmitted down to younger generations by word of mouth and simple role plays. This system of knowledge management complimented by the use of taboos indeed managed to preserve some of the most important institutions and resources in society.

Some of the natural resources that have been conserved up till this day have become very important in the contemporary economy. Specifically, the ironwood (Lophira alata or 'mubvamaropa' in Shona) trunk is being used as a medicine for back pain and toothache. What probably lacks is the formal commercial harvesting of the medicine into the laboratories. Traditional medicines are taking a more prominent role in Zimbabwe's primary healthcare delivery system mainly because of the worsening economic challenges. The growing population and the destruction of wooded areas for the creation of agricultural land are exerting more pressure on the sources of traditional medicines leading to a dire shortage of the end-products.

\section{Challenges to Biodiversity}

Colonialism restructured indigenous knowledge and conservation systems so much so that what people know about some of the traditional systems today comes from the ideologically tinted lenses of colonial researchers who recorded some African cultures as backward, raw and archaic in an effort to defend colonisation (Eyong et al., 2004). It has been documented and is widely appreciated that, colonialism basically subdued the growth of indigenous technology in Africa and weakened a 
number of of the existing processes of technological development and the indigenous conservation systems. This in the Karanga area of Zvishavane was perpetuated through the removal of genuine traditional leaders and replaced by colonial puppets who had no capacity to police and preserve local heritage systems.

Biodiversity has also been heavily affected by economic challenges. What has generally happened in most African states is that economic down-turns have forced people to ignore their traditional systems for the contemporary ones which are thought to bring sustenance and quick development. Zvishavane has not been spared either in this crisis. Due to economic challenges, most youth have migrated to the urban areas in search of employment leaving their rural areas and all their knowledge systems. Closely akin to the above is the problem related to globalisation. Globalisation and modernity have crowded the world market with information and knowledge about the developed world systems suffocating the developing especially Africa (Polikanov and Abramova, 2003). Failure to support local material and systems, the western media will obliterate indigenous culture and rob all potential cultural growth.

Human displacement has been observed to be another challenge bedevilling the growth of traditional systems of conservation in the developing world (Eyong et al, 2004). Zvishavane like any other district in Masvingo has been undergoing some infrastructural development since the political independence in 1980. Therefore, some of those developments have seen people forcibly moved leaving their cultural heritage naturally dying. For those spared from development and forced relocation, they suffer from social exclusion by either political or sub-ethnic factions. The practice of foreign religiosity in Zvishavane district and the entire Masvingo province has also worked to the obliteration of the concept of traditional conservation of biodiversity. Some Christian religious groups regard traditional culture as evil and barbaric and even discourage their membership from following their ancestral traditions. That way, traditional cultural systems are either eroded or suppressed.

It has been realised that there are some policies by government that are inclined towards excluding the participation of the local populace in the preservation of environmental resources. As a result, people tend to naturally want to sort of rebel and deliberately break all the existing laws.

\section{Contemporary Conservation}

In view of the globalisation processes experienced the world over, conservation methods have equally transformed over the period to match the contemporary dictates on resource management. Therefore, state actors and some municipal laws have been roped in to support contemporary conservation efforts. With regards to the conservation of natural resources and institutions; the Zimbabwean government passed the Traditional Medicines Act of 1981, dedicated itself to the decentralization of the management responsibilities of natural resources to local communities through programmes like the Communal Areas Management Programme for Indigenous Resources (CAMPFIRE) and District Environment Action Plan (DEAP) amongst others. 


\section{References}

Amobola O. C. (2013) An Overview of Taboo and Superstition among the Yoruba of Southwest of Nigeria. Mediterranean Journal of Social Sciences, Vol.4/2, p.221-227

Chigidi W. L. (2009). Shona Taboos: The Language of Manufacturing Fears for Sustainable Development. The Journal of Pan African Studies, (3)1, p. 174-188.

Dodo O. (undated) Taboo Systems, A Conflict Restraint In The Political Feud In Zimbabwe. An Exploration of Mazowe and Shamva Districts, Post Independence. On-going PhD Thesis with UniLus, Zambia.

Eyong, C.T., M. Mufuaya, and I.I. Foy. (2004) Literature and Culture - The Sustainability Connection from an African Perspective, in Regional Sustainable Development Review: Africa. Oxford: Eolss Publishers.

Fabricius, C. (2004) “The fundamentals of community-based natural resource management," in Rights, resources and rural development: community-based natural resource management in southern Africa. (ed) C. Fabricius and E. Koch, pp. 2-43. London: Earthscan.

Gelfand, M. (1979). Growing Up in Shona Society. Gweru: Mambo Press.

Haralambos, M. and Holborn, M. (2000). Introduction to Sociology: Themes and Perspectives. 4th edition, London: Collins.

Kagan M. (2012). What is superstition? Whyzz. Publications LLC.

Kilonzo S. M, S. G. Kurgat, and S. G. Omare (2009) The Role of Taboos in the Management of Natural Resources and Peace-building: A Case Study of the Kakamega Forest in Western Kenya. Africa Peace and Conflict Journal, Vol. 2/1 (June), p.39-54

Kumar,V. (2009). Reasons why people believe in superstitions www.helium.com/items/1602118reasons-for-superstitions-whysuperstitions-explaining-superstitions-why-superstitions

Accessed 7/9/13.

Madu, S. N. (2002). Health Complaints of High School Students in the Northern Province and Taboo Themes in Their Families. South African Journal of Education, Vol. 22(1), p.65-69.

Masaka D. and M. Chemhuru (2011) Moral Dimensions Of Some Shona Taboos (Zviera). Journal of Sustainable Development in Africa Vol. 13/3, p132-148.

Mashall G. 1994 The Concise Oxford Dictionary of Sociology. London, Routledge.

Meakin S. 1993 Biodiversity: Its Importance In The Modern World Conference Report. Paper Presented At The Science And Technology Division, 6 April 1993, Parliamentary Research Branch (p.1-6)

Melchias, G. 2001. Biodiversity and Conservation. Enfield: Science Publishers, Inc.

Mohamed-Katerere, J. C., and M. Chenje. (2002) Environmental law and policy in Zimbabwe. Harare: SARDC. 
Mukwada G. 2008 Voices from the Past and Echoes of the Future: Management of Forest and Woodland Resources by Local Religious Institutions within the Mufurudzi Resettlement Scheme in Zimbabwe. Journal of Ecological Anthropology, Vol. 12, p.39-53.

Ndlovu-Gatsheni J. S. (2008) The Ndebele Nation. Hegemony, Memory, Historiography Rozenberg Quarterly Magazine. Rozenberg Publishers, UNISA Press.

Nhira C. and L. Fortmann (1993) "Local woodland management: Realities at the grassroots," in Living with trees: Policies for forestry management in Zimbabwe: World Bank Technical Paper No. 210. (ed) P.N. Bradley and K. McNamara, p.139-155. Washington, DC: World Bank.

Pfukwa, C. (2001). "Unwritten Ethics and moral Values: The Human face of Chimurenga ii", in Vambe, M.T. (Ed) Orality and Cultural Identities in Zimbabwe, p 25-36. Gweru: Mambo Press.

Polikanov, D. and I. Abramova. (2003) Africa and ICTs: A Chance for Breakthrough? Information, Communication and Society, Vol.6/1, p.42-56.

Ranger T. (2003) "Women and environment in African religion," in Social history \& African environments. (ed) W. Beinart and J. McGregor, p. 72-86. Oxford: James Currey Publishers.

Sithole M. and Makumbe J. (1997) Elections in Zimbabwe: The ZANU (PF) Hegemony and its Incipient Decline. African Journal of Political Science. Vol. 2/1, p.122-139

Tatira, L. (2000b). The Role of Zviera in Socialisation. In E. Chiwome, Z. Mguni \& M. Furusa (Eds.), Indigenous Knowledge and Technology in African and Diasporan Communities. (pp. 146-151). Harare: University of Zimbabwe. 